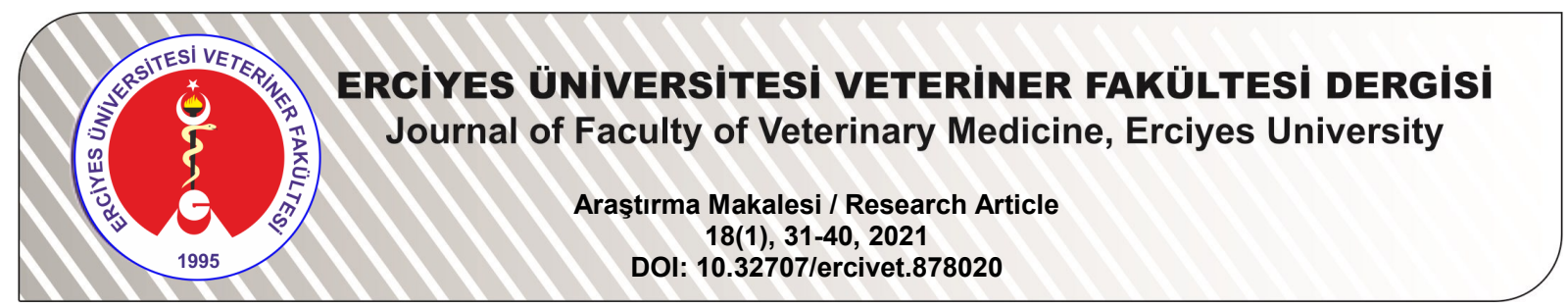

\title{
Veteriner Fitoterapi ve Etnoveteriner Hekimlikte de Kullanılan Thymbra spicata L., Rosmarinus officinalis L. ve Laurus nobilis L. Bitkilerinin Kimyasal İçeriklerinin Belirlenmesi
}

\author{
Mustafa YIPEL ${ }^{1}$, Sara Büşra EMiROĞLU¹, Musa TÜRKMEN² ${ }^{2}$ Erdinç TÜRK ${ }^{1}$, Aysun ILHAN ${ }^{1}$, \\ Fatma Ceren KIRGIZ1', İbrahim Ozan TEKELi' \\ ${ }^{1}$ Hatay Mustafa Kemal Üniversitesi, Veteriner Fakültesi, Farmakoloji ve Toksikoloji Anabilim Dalı, Hatay-TÜRKIYE \\ ${ }^{2}$ Hatay Mustafa Kemal Üniversitesi, Ziraat Fakültesi, Tıbbi Aromatik Bitkiler Anabilim Dalı, Hatay-TÜRKIYE
}

Sorumlu yazar: Sara Buşra EMIROĞLU; E-posta: sarabusraemiroglu@gmail.com; ORCID: 0000-0003-0855-4967

Atıf yapmak için: Yipel M, Emiroğlu SB, Türkmen M, Türk E, Kırgız FC, Tekeli IO. Veteriner fitoterapi ve etnoveteriner hekimlikte de kullanılan Thymbra spicata L., Rosmarinus officinalis L. ve Laurus nobilis L. bitkilerinin kimyasal içeriklerinin belirlenmesi. Erciyes Univ Vet Fak Derg 2021; 18(1): 31-40

Özet: Bitki ve bitkisel materyaller veteriner fitoterapi ve etnoveteriner hekimlik uygulamaları içerisinde önemli bir yere sahiptir. Bitkiler tarafından sentezlenen bazı biyoaktif kimyasal bileşenler medikal etkilere sahiptir. Ancak bu bitki ve bitkisel materyallerin kullanımları; teşhisteki yanlışlıklar, doz ayarlama güçlüğü, geleneksel kullanımlarına dair yazılı kayıt ve bilimsel çalışmaların yetersizliği, düşük hijyen koşulları ve toplandığı bölgeye, mevsime, kullanılan kısmına ve elde edildiği yönteme göre sahip oldukları kimyasal kompozisyonlarının değişmesi gibi nedenlere bağlı olarak zehirlenmeler meydana getirebilmektedir. Çalışma kapsamında Hatay bölgesinde yetişen, veteriner fitoterapi ve etnoveteriner hekimliğinde de kullanılan Thymbra spicata var. spicata L., Rosmarinus officinalis L. ve Laurus nobilis L. bitkilerinin içerdikleri biyoaktif kimyasal maddelerin kompozisyonları belirlenmiştir. Solvent ekstraksiyonu yöntemiyle elde edilen bitki ekstraksiyonlarının kimyasal kompozisyonları gaz kromatografisi kütle spektrofotometresi (GC-MS) ile belirlendi. Analiz sonucunda $R$. officinalis $\mathrm{L}$. ve $L$. nobilis $\mathrm{L}$.'in ana bileşenleri sırasıyla $\% 38.91$ ve $\% 33.70$ oranlarında $1,8-$ sineol (ökaliptol) olarak tespit edildi. T. spicata var. spicata L.'nın ana bileşeni ise karvakrol (\%48.82) olarak belirlendi. Bu bileşenlerin antimikrobiyal, antienflamatuar ve antioksidan etkileri yanında karaciğer, böbrek, pankreas ve testis gibi organ hasarları, DNA iplik kopmaları ve solunum problemleri gibi istenmeyen ve zehirli etkilere de yol açtığı bildirilmiştir. Bu nedenle hayvan sağlığında da kullanılan tıbbi bitki ve bitkisel materyallerin ana bileşen ve oranının bilinmesinin potansiyel toksik etkilerin önlenebilmesi açısından önemli olduğu düşünülmektedir.

Anahtar kelimeler: Biyoaktif bileşenler, etnoveteriner hekimlik, solvent ekstraksiyon, toksikoloji, veteriner fitoterapi

Determination of Chemical Contents of Thymbra spicata L., Rosmarinus officinalis L. and Laurus nobilis L., Also Used in Veterinary Phytotherapy and Ethnoveterinary Medicine

Summary: Plants and herbal substances have an important place in veterinary phytotherapy and ethnoveterinary medicine applications. Some bioactive chemical compounds synthesized by plants have medical effects. However, the use of these plants and herbal materials can cause poisoning due to wrong identification, difficulty in adjusting its dosage, insufficiency of written records and scientific studies on their traditional use, poor hygienic conditions in preparation and variation in their chemical composition according to the region, where and the season when they are gathered, their used part, and their extraction method. In our study, it was aimed to determine the chemical compositions and to toxicologically evaluate the major compounds of $T$. spicata var. spicata L., Rosmarinus officinalis L., and Laurus nobilis $L$. grown in Hatay region and used in veterinary phytotherapy and ethnoveterinary medicine. Chemical compositions of plants contents obtained by solvent extraction method were determined by gas chromatography mass spectrophotometry (GC-MS) analysis. The major components of $R$. officinalis $\mathrm{L}$. and $L$. nobilis $\mathrm{L}$. were determined as 1,8 -cineol (eucalyptol), in rates of $38.91 \%$, and $33.70 \%$ respectively. The major component of $T$. spicata var. spicata L. was determined as carvacrol $(48.82 \%)$. While these components have antimicrobial, anti-inflammatory and antioxidant effects, it has also been reported to cause undesirable and toxic effects such as organs damages (liver, kidney, pancreas and testes etc.), DNA thread breaks and respiratory problems. For this reason, it is thought that knowing the major components and their ratios of medicinal plants and materials used in animal health is important in terms of preventing potential toxic effects.

Key words: Bioactive components, ethnoveterinary medicine, solvent extraction, toxicology, veterinary phytotherapy

\section{Giriş}

Veteriner fitoterapi (VFT); hayvan hastalıklarının profilaksi ve tedavisinde bitki ve bitkisel materyallerin

Geliş Tarihi/Submission Date : 27.07.2020

Kabul Tarihi/Accepted Date $\quad: 23.11 .2020$ (fitofarmasötiklerin) kullanımı olarak tanımlanmaktadır (Altınok Yipel ve Yipel, 2014; Yipel ve ark., 2018). Fitofarmasötiklerin de içerisinde yer aldığı; hayvanlarda verim ve refahın artırılmasıyla hastalıklardan korunma ve tedavide başvurulan bölgesel farklılıklara sahip geleneksel uygulamalar (bitkisel, hayvansal, 
manevi, manipülatif, cerrahi vb.) ise etnoveteriner hekimlik (EVH) olarak tanımlanmaktadır. 1980'li yıllarda EVH'likle ilgili belgelerin ortaya çıkmasıyla asırlardır deneme yanılma yoluyla nesiller arası aktarılmış holistik ve interdisipliner uygulamalara dayalı bilgiler bilimsel bir zeminde incelenmeye başlanmıştır. Günümüzde ise hayvan sağlığı alanında hem hayvan sahipleri hem de veteriner hekimler tarafından geleneksel, modern veya alternatif uygulamalar (EVH, VFT vb.) içerisinde bitki ve bitkisel ürünlerin kullanımı gün geçtikçe artmaktadır (Altınok Yipel ve Yipel, 2014).

Bitki ve bitkisel kaynaklardan elde edilen materyallerin insanlık tarihinin erken dönemlerinden bu yana insan ve hayvan hastalıklarının tedavisinde kullanıldığı bilinmektedir. Ancak 18. yüzyılda kimya biliminin gelişmesi ve devamında ise sentetik ve yarı sentetik maddelerin üretimindeki artış bitkisel maddelerin kullanımında azalmaya neden olmuştur. Modern ilaçların yan etkilerinin belirlenmesiyle doğal kaynaklardan elde edilen maddelerin kullanımı zamanla artmaya başlamıştır (Karaoğlan ve Özgen, 2011). Bu nedenle günümüzde bitki ve bitkisel maddelerin kullanımı oldukça yaygındır.

Tıbbi bitkiler tarafından sentezlenen biyoaktif kimyasal bileşenler medikal etkilere sahiptirler. Güncel veriler dünya genelinde insanların \%80'inin, Afrika da ise $\% 95$ 'inin bitkisel tedavi yöntemlerine başvurduklarını göstermektedir. Ayrıca, son 35 yılda geliştirilen ilaçların \%70'inden fazlası doğal kaynaklara dayanmakta ve reçeteli ilaçların yaklaşık \%25'i bitkisel kaynaklıdır (Güzel ve ark., 2015).

Etnoveteriner hekimlik kapsamındaki uygulamalar; düşük maliyetli, kolay ulaşılabilir, çevre dostu, doğal kaynaklardan elde edilen maddelerin kullanılması gibi birçok avantaj yanında kullanımları açısından bitki teşhisindeki yanlışlık riski, dozlama güçlüğü, yazılı kayıtların sınırlı olması, bilimsel çalışmaların yetersizliği ve hijyen standartlarının düşük olması gibi dezavantajlara da sahiptir (Altınok Yipel ve Yipel, 2014). Ayrıca EVH'de kullanılan bitkilerle ilgili yapılan bilimsel çalışmaların çoğu kimyasal içerikleri, sahip oldukları klinik ve terapötik etkileriyle ilgiliyken, toksikolojik özellikleriyle ilgili çalışmalar oldukça sınırıdır. Bu nedenle özellikle hekim kontrolü dışında kullanımlar sonucunda bitkisel ürünlerle ilgili ölümle sonuçlanabilen yan etkiler bildirilmiştir. Bu yan etkiler, doğrudan toksisite, kontaminasyon, ilaçlar veya diğer bitkilerle etkileşimler dahil olmak üzere birkaç farklı mekanizma ile ortaya çıkabilmektedir (Peixoto ve ark., 2010). İnsanlar arasında kozmetik ve tıbbi açıdan bitki ve bitkisel madde kullanımının tamamıla zararsız olduğuyla ilgili yanlış olan düşünce oldukça yaygındır. Unutulmamalıdır ki doz ilaçla zehir arasındaki sınırı belirleyen öncelikli parametredir. Tıbbi bitkilerin etki ve toksisitelerini değerlendirmek için bileşenlerinin doza bağlı biyolojik aktivitelerinin bilimsel çalışmalarla belirlenmesi gerekmektedir (Peixoto ve ark., 2010).

Türkiye, 174 aile ve 125000 türe ait 12000'den fazla tür ve alt türden oluşan bir taksonla zengin bir bitki florasına sahiptir. Tüm Avrupa'da toplam endemik bitki sayısı 2750 iken, tür oranı ve çeşitliliği açısından Ortadoğu'nun en zengin florasına sahip Türkiye'de bu sayı 2891'dir. Türkiye'nin Akdeniz (Güney) bölgesi, 497 endemik alt tür ve 390 çeşitle diğer bölgelere göre en geniş endemik bitki çeşitiliğine sahip bölgedir (Kendir ve Güvenç, 2010).

Thymbra spicata var. spicata L., Türkiye'nin birçok bölgesinde (Güneydoğu Anadolu, Trakya, Ege ve Akdeniz) yetişen, çalı görünümlü, yaklaşık $50 \mathrm{~cm}$ yüksekliğinde yaprak dökmeyen Labiatae ailesinin bir türüdür. Yaprakları taze ya da kurutulmuş olarak kullanılabilen bitki, sahip olduğu aromatik ve tıbbi özellikleri nedeniyle gün geçtikçe artan bir ekonomik değere sahiptir (Lee ve ark., 2005; Mert ve ark., 2016). Bölgesel olarak kekik, kaya kekiği, zahter olarak da adlandırılan $T$. spicata var. spicata L.etnotıpta genellikle antiseptik, ekspektoran, kramp çözücü ve antimikrobiyal etkileri için kullanılmaktadır. Hayvan sağlığı alanında kullanımıyla ilgili sınırlı bilgi bulunan $T$. spicata var. spicata L.'nın biyokimyasal kompozisyon açısından ülkemizde de yetişen diğer kekik (Thymus spp. ve Oreganum spp.) türleriyle benzerlik gösterdiği ve bu türlerinde yüksek oranda karvakraol içerdiğ rapor edilmiştir (Azcan ve ark., 2000; Tohidi ve ark., 2017). Thymbra spicata var. spicata $L$. ve diğer kekik türlerinin EVH ve VFT'de yaprak ve kök kısımları, enteral ya da lokal formülasyonlar şeklinde gastrointestinal sistem ve dermal hastalıkların tedavisinde kullanıldığı bildirilmiştir (Benli ve Yiğit, 2005; Wynn ve Fougere, 2006; Yipel ve ark., 2017).

$R$. officinalis L., Labiatae ailesinden dik saplı, beyazımsı mavi çiçek ve koyu yeşil yapraklara sahip, yaklaşık bir metre yüksekliğe ulaşabilen, yaprak dökmeyen çalı formlu bir türdür. Akdeniz'in kuzey ve güney kıyılarıyla Himalaya'nın alt bölgelerinde yabani olarak yetişmektedir (Al-Sereiti ve ark., 1999). Türkçe olarak biberiye, haslban ve kuşdili gibi isimlerle bilinmektedir (Özcan ve Chalchat, 2008). R. officinalis L. bitkisinin antiseptik, antiparazitik, antidiyabetik, diüretik, antispazmodik, antiromatizmal ve mide yaralarının tedavisi amacıyla kullanılmaktadır (Al-Sereiti ve ark., 1999; Lahlou ve Berrada 2003; Özcan ve Chalchat, 2008). Biberiyenin farmakolojik ve terapötik özelliklerinin araştırıldığı bir yayında $R$. officinalis L. bitkisinin esansiyel yağının antihepatotoksik, antimikotik, antitümorojenik etkilerinin olduğu bir çok çalışmadan bahsedilmiştir (Al-Sereiti ve ark., 1999). Ayrıca EVH ve VFT'de yaprak ve çiçekleri enteral ya da lokal olarak gastrointestinal sistem, üreme ve dermal hastalıkların tedavisinde antienflamatuar, sedatif, antibakteriyel ve antifungal olarak kullanılmaktadır. Atlarda antienflamatuar olarak da kullanıldığı bildirilmiştir (Wynn ve Fougere, 2006; Yipel ve ark., 2017). 
L. nobilis L. (defne) Türkiye, Cezayir, Yunanistan gibi Akdeniz ülkeleri yanında Avrupa (Belçika, Fransa), Asya ve Güney Amerika (Meksika) da doğal olarak yetişmektedir. Akdeniz defnesi bazen bodur bazen de boylu ağaççık formundadır. Halk arasında har, teynel ve gar olarak da adlandırılan defne, sabun yapımında sık kullanılmaktadır. L. nobilis L. etnotıpta yaprakları uykusuzluk giderici ve ağrı kesici olarak kullanılmaktadır. Yapılan çalışmalarda analjezik ve antiseptik, mide rahatsızlıklarını giderici, antidiyabetik, halsizlik giderici, hazımsızlık ve migren önleyici gibi özellikleri de bildirilmiştir (Karık ve ark., 2015). Laurus nobilis L. Akdeniz'de yetişen, anavatanı Balkanlar ve Anadolu olan, $15 \mathrm{~m}$ kadar değişen boylara sahip yuvarlak tepeli, sık dallı dört mevsim yeşil ağaçlardır. Yapraklar farklı şekillerde, $11 \mathrm{~cm}$ boyunda, 2-4 cm genişliğindedir. Gövde kabuğu, düzgün, çatlaksız, koyu gri renklidir. Türkiye'de Akdeniz, Ege, Marmara ve Karadeniz kıyılarında doğal olarak yetişmektedir (Akkemik, 2018). Dekoratif park bitkisi olması yanında aynı zamanda odun dışı orman ürünü olarak kullanımı önemlidir. Yaprak ve meyve yağı eczacılıkta ve sabun endüstrisinde, yapraklarının kurutulmuş hali ise baharat olarak kullanılmaktadır (Akkemik, 2018). L. nobilis L. VFT'de atlarda enteral ya da lokal formülasyonlar şeklinde iştah uyarıcı ve dermal hastalıkların tedavisinde kullanılmaktadır (Wynn ve Fougere, 2006; Yipel ve ark., 2017).

Tıbbi ve aromatik özelliğe sahip bitkiler, insanlık tarihinin ilk dönemlerinden beri insan ve hayvanlar için vazgeçilmez olmuştur. İnsan ve hayvan hastalıklarında yaygın olarak kullanılan bitkilerin terapötik etkileri hem uzun yıllar deneme yanılma yoluyla hem de bilimsel araştırmalar doğrultusunda tespit edilmiştir. Bitkilerin insan ve hayvan sağlığında hekim kontrolü dışında kullanımı, yanlış teşhisi, eksik veya yanlış hazırlanması, endikasyon dışı ya da yanlış miktarlarda kullanılmaları sonucunda toksikasyon gerçekleşebilmektedir. Bu nedenle son yıllarda bitki ve bitkisel materyallerin toksikolojik özelliklerinin bilinmesi zorunlu hale gelerek, konuyla ilgili çalışmaların artmasına neden olmuştur (Peixoto ve ark., 2010).

Çalışmanın temel amacı yüzyıllardır insan ve hayvan sağlığında $E V H$ 'de kullanılan, günümüzde VFT'de kullanımı gün geçtikçe artan bitki ve ekstraklarının içerdiği biyoaktif kimyasal bileşenlerin aynı zamanda toksik etkilerinin de olabileceğini vurgulamaktır. Bu amaç doğrultusunda çalışmada Hatay bölgesinde yetişen EVH ve VFT de kullanılan tıbbi bitkilerden 3'ünün ( $T$. spicata var. spicata L., $R$. officinalis $L$. ve $L$. nobilis L.) kimyasal kompozisyonu belirlenmiştir.

\section{Gereç ve Yöntem}

Çalışmada Hatay bölgesinde doğal olarak yetişen ve veteriner fitoterapi ile EVH'de de kullanılan tıbbi bitkilerden T. spicata var. spicata $L$. ve $R$. officinalis $L$. çiçeklenme, $L$. nobilis $L$. ise çiçeklenme sonrası (Şekil 1) dönemde Antakya florasından toplanarak teşhis edildi. Bitkiler oda sıcaklığında $\left(20-28^{\circ} \mathrm{C}\right)$ kurutulduktan sonra yapraklar bitkinin diğer kısımlarından ayırıldı ve kurutulup öğütülerek ekstraksiyona hazır hale getirildi.

Çalışmada bitkilerde bulunan biyoaktif kimyasal bileşenlerin ekstraksiyonu için solvent olarak metanol (Merck $^{\circledR}$ 1.06007.2500, Almanya) seçildi. Toplanan bitkiler öğütücüde (Lavion ${ }^{\circledR}$, Çin) toz haline getirildi. Her bir bitkiden $50 \mathrm{~g}$ tartılarak bir cam şişe içerisine alındı ve üzerlerine 125 'er $\mathrm{ml}$ metanol eklenerek manyetik karıştırıcıda (M TOPS ${ }^{\circledR}$ HS15-03P, Güney Kore) 24 saat boyunca ekstraksiyona bırakıldı. İşlem sonunda ekstraktlar, filtre kağıdıyla süzüldü (AlRubaye ve ark., 2017). Ekstraktlar ile analizi yapılıncaya kadar $+4{ }^{\circ} \mathrm{C}$ 'de saklandı. Ekstraktların kimyasal kompozisyonları gaz kromatografisi kütle spektrofotometresi (GC-MS) analiziyle belirlendi. Bu işlem GS-MS (Thermo Scientific ISQ Single Quadru-
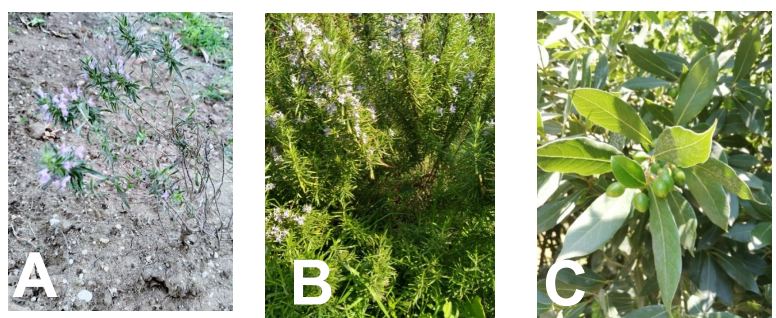

Sekil 1. Calısmada kimyasal kompozisyonyarı belirlenerek toksikolojik yönden incelenen ve Hatay bölgesinde yetişen $T$. spicata var. spicata L. (A), R. officinalis L. (B) ve L. nobilis $L$. $(C)$ bitkilerinin sırasıyla verilen genel görünümleri

Tablo 1. Gaz kromatografisi kütle spektrofotometresi (GC-MS) analiz koşulları

\begin{tabular}{cc}
\hline Cihaz & Thermo Scientific ISQ Single Quadrupole \\
\hline Kolon & TR-FAME MS model, \%5 Fenil Polisilfenilen-siloksan, $0.25 \mathrm{~mm}$ iç çap x $60 \mathrm{~m}$ \\
uzunlukta, $0.25 \mu \mathrm{m}$ \\
İyonizasyon 22 enerjisi & $70 \mathrm{eV}$ \\
Kütle aralığı m/z & $1.2-1200 \mathrm{amu}$ \\
MS transfer line sıcaklığı & $250{ }^{\circ} \mathrm{C}$ \\
MS iyonizasyon sıcaklığı & 220 \\
Enjeksiyon port sıcaklığı & $220{ }^{\circ} \mathrm{C}$ \\
Kolon sıcaklığı & $50-220^{\circ} \mathrm{C}\left(3^{\circ} \mathrm{C} /\right.$ dak $)$ \\
Helyum (\%99.9) akış hızı & $1 \mathrm{~mL} /$ dak \\
Veri toplama modu & Scan Mode \\
Kütüphane & Xcalibur progamı (Wiley 9) \\
\hline
\end{tabular}


pole, USA) cihazıyla Tablo 1'de verilen koşullarda gerçekleştirildi.

\section{Bulgular}

Yirmi dört saatlik metanol ekstraksiyonu sonucunda elde edilen bitki ektraktlarının GC-MS analizi sonucunda $T$. spicata var. spicata L.,bitkisinin bileşenleri incelendiğinde toplam 45 kimyasal bileşen madde belirlendi. Ana bileşenleri olarak karvakrol (\%48.82) ve $y$-terpinen (\%33.79) tespit edildi (Tablo 2).

Rosmarinus officinalis L. bitkisinden elde edilen ekstraksiyonun bileşenleri incelendiğinde ise 42 kimyasal bileşen belirlendi. Ana bileşenleri olarak 1,8-sineol (ökaliptol) (\%38.91) ve $\alpha$-pinen (\%11.25) olarak tespit edildi (Tablo 3).

Laurus nobilis L. bitkisinde ise toplam 44 kimyasal bileşen belirlendi. Ana bileşenleri olarak 1,8-sineol (\% 33.70) ve $\alpha$-terpinil asetat (\%22.28) tespit edildi (Tablo 4).

Tablo 2. Thymbra spicata var. spicata L.bitkisi kimyasal bileşenleri

\begin{tabular}{|c|c|c|c|}
\hline Sıra & RT & Yüzde (\%) & Bileşenler \\
\hline 1 & 8.41 & 0.21 & $\beta$-Pinen ${ }^{\mathrm{a}}$ \\
\hline 2 & 8.96 & 1.22 & Mirsen $^{a}$ \\
\hline 3 & 9.41 & 0.21 & $\alpha-$ Felandren $^{\mathrm{a}}$ \\
\hline 4 & 11.12 & 33.79 & y-Terpinen ${ }^{a}$ \\
\hline 5 & 12.64 & 2.75 & o-Simen ${ }^{a}$ \\
\hline 6 & 19.62 & 0.17 & cis-Sabinen hidrat $^{a}$ \\
\hline 7 & 6.50 & 1.18 & $\alpha-$ Tujen $^{\mathrm{b}}$ \\
\hline 8 & 22.87 & 0.18 & trans Sabinen hidrat ${ }^{\mathrm{b}}$ \\
\hline 9 & 26.96 & 0.17 & $a-$ Terpineol $^{b}$ \\
\hline 10 & 27.50 & 0.13 & |zoborneol $^{\mathrm{C}}$ \\
\hline 11 & 38.75 & 0.42 & Timol $^{\mathrm{C}}$ \\
\hline 12 & 39.88 & 48.82 & Karvakrol $^{c}$ \\
\hline 13 & 25.87 & 1.52 & $\beta$-Bisabolene ${ }^{d}$ \\
\hline 14 & 49.85 & 0.56 & Fitol $^{\mathrm{e}}$ \\
\hline 15 & 17.06 & 0.06 & 1-Octen-3-ol ${ }^{f}$ \\
\hline 16 & 9.82 & 2.52 & $\alpha-$ Terpinen $^{g}$ \\
\hline 17 & 12.00 & 0.13 & 1-Terpinenol ${ }^{g}$ \\
\hline 18 & 13.31 & 0.14 & Etil metil eter ${ }^{g}$ \\
\hline 19 & 17.82 & 0.04 & $\beta$-Hidroksietil akrilat ${ }^{9}$ \\
\hline 20 & 20.64 & 0.08 & cis-Limonen oksit $^{9}$ \\
\hline 21 & 23.46 & 0.06 & 9-exo-methyl-anti(9.10)-tricyclo[4.2.1.1(2.5)] dec-3-en-9-endo-ol ${ }^{9}$ \\
\hline 22 & 24.17 & 0.99 & trans-Karyofilen ${ }^{9}$ \\
\hline 23 & 25.01 & 0.06 & Ledene $^{\mathrm{g}}$ \\
\hline 24 & 28.41 & 0.34 & trans-p-Mentha-1(7).8-dien-2-ol ${ }^{g}$ \\
\hline 25 & 32.60 & 0.15 & Neophytadiene ${ }^{g}$ \\
\hline 26 & 32.72 & 0.11 & 9-Eicosyne ${ }^{g}$ \\
\hline 27 & 34.39 & 0.06 & 9-Octadecenoik asit (Z)-. Fenilmetil ester ${ }^{9}$ \\
\hline 28 & 34.76 & 0.53 & 3-Metil-4-izopropil fenol ${ }^{g}$ \\
\hline 29 & 35.41 & 0.07 & 2.5-Dimetil-4-hydroksi-3(2H)-furanone ${ }^{g}$ \\
\hline 30 & 37.90 & 0.11 & $\operatorname{Timin}^{\mathrm{g}}$ \\
\hline 31 & 38.44 & 0.10 & Penol. 2-(1.1-dimetiletil)- ${ }^{\mathrm{g}}$ \\
\hline 32 & 40.50 & 0.20 & 2- Metoksimesitilen ${ }^{9}$ \\
\hline 33 & 41.30 & 0.06 & Ascaridole epoksit ${ }^{9}$ \\
\hline 34 & 41.87 & 0.54 & 1-Naphthalenol ${ }^{9}$ \\
\hline 35 & 42.09 & 0.05 & 7-Oxabicyclo[4.1.0]heptan. 1-metoksi-2.2.6-trimetil- ${ }^{\mathrm{g}}$ \\
\hline 36 & 42.41 & 0.08 & Eicosahydrodibenzo(a.i)fluorene ${ }^{\mathrm{g}}$ \\
\hline 37 & 42.52 & 0.13 & 2-Metoksi-4-vinilfenol ${ }^{9}$ \\
\hline 38 & 43.97 & 0.09 & 1- Vinil (ethenyl) siklohekzanol ${ }^{g}$ \\
\hline 39 & 45.56 & 0.08 & y-Butil-y-bütirolakton ${ }^{9}$ \\
\hline 40 & 46.36 & 0.37 & 1-Penten-3-ol ${ }^{g}$ \\
\hline 41 & 47.21 & 0.41 & 3-Furanol. tetrahidro- ${ }^{9}$ \\
\hline 42 & 49.37 & 0.05 & 5-Asetildihidro-2(3H)-furanone $\mathrm{g}^{\mathrm{g}}$ \\
\hline 43 & 50.44 & 0.05 & Cholestan-3-ol. 2-metilen-9 \\
\hline 44 & 52.72 & 0.26 & Izopropil metil nitrözamin 9 \\
\hline 45 & 53.34 & 0.40 & 5-Hidroksimetilfurfural ${ }^{9}$ \\
\hline
\end{tabular}

Bileşenlerin bulunduğu gruplar; a: Monoterpen hidrokarbon, b: Oksijenli monoterpen, c: Monoterpen, d: Hidrokarbon Siskiterpen, e: Diterpen, f: Hidrokarbon, g: Diğer. 
yan kişiler tarafından tavsiye edilmesi ya da kullanılması sonucunda ciddi yan etkiler meydana gelebilmektedir (George, 2011). Bu durumda bitki ve bitkisel materyallerin toksikolojik özelliklerinin bilinmesini zorunlu hale getirerek, konuyla ilgili çalışmaların artmasına neden olmuştur (Peixoto ve ark., 2010).

Tablo 3.Rosmarinus officinalis L. bitkisi kimyasal bileşenleri

\begin{tabular}{|c|c|c|c|}
\hline Sıra & RT & Yüzde (\%) & Bileşenler \\
\hline 1 & 6.59 & 11.25 & $a-P_{i n e n}{ }^{a}$ \\
\hline 2 & 7.61 & 2.24 & Kampen $^{\mathrm{a}}$ \\
\hline 3 & 8.44 & 0.20 & Carene $^{a}$ \\
\hline 4 & 9.00 & 2.74 & Mirsen $^{a}$ \\
\hline 5 & 10.05 & 2.51 & Limonen $^{a}$ \\
\hline 6 & 11.18 & 0.10 & $y$-Terpinen ${ }^{a}$ \\
\hline 7 & 12.68 & 3.51 & p-Simen ${ }^{a}$ \\
\hline 8 & 12.07 & 38.91 & Ökaliptol $(1,8 \text {-sineol })^{b}$ \\
\hline 9 & 20.65 & 0.39 & Linalool $^{\mathrm{b}}$ \\
\hline 10 & 25.97 & 8.29 & Kâfur b \\
\hline 11 & 26.96 & 4.80 & $\alpha$-Terpineol ${ }^{b}$ \\
\hline 12 & 27.52 & 6.89 & Borneol $^{b}$ \\
\hline 13 & 31.65 & 0.18 & $p$-Simen-8-ol ${ }^{b}$ \\
\hline 14 & 23.31 & 0.10 & 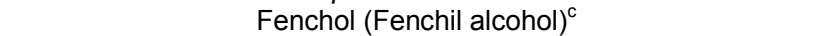 \\
\hline 15 & 33.51 & 0.64 & Verbenone ${ }^{c}$ \\
\hline 16 & 38.48 & 0.15 & Timol $^{c}$ \\
\hline 17 & 39.77 & 0.14 & Karvakrol $^{d}$ \\
\hline 18 & 24.19 & 5.80 & trans-Karyofilen ${ }^{\mathrm{e}}$ \\
\hline 19 & 37.92 & 0.10 & Metil Ögenol $^{f}$ \\
\hline 20 & 38.25 & 0.35 & Karyofilen oksit ${ }^{9}$ \\
\hline 21 & 39.53 & 0.16 & Globulol $^{\mathrm{h}}$ \\
\hline 22 & 40.74 & 0.16 & Ögenolj \\
\hline 23 & 41.32 & 0.20 & Retinal $^{k}$ \\
\hline 24 & 17.11 & 0.12 & 1-Octen-3-ol ${ }^{\mathrm{m}}$ \\
\hline 25 & 13.5 & 0.17 & Asetik asit \\
\hline 26 & 25.32 & 1.92 & Asetik asit. 1.7.7-trimethyl-bicyclo[2.2.1]hept-2-yl ester ${ }^{n}$ \\
\hline 27 & 26.62 & 1.32 & L-a-Terpineol ${ }^{n}$ \\
\hline 28 & 40.6 & 0.09 & Bornanediol $^{n}$ \\
\hline 29 & 41.99 & 0.22 & 2-Propil-tetrahidropiran-3-ol ${ }^{\mathrm{n}}$ \\
\hline 30 & 42.55 & 0.38 & 4-Hidroksi-2-methilasetofenon ${ }^{n}$ \\
\hline 31 & 44.61 & 1.79 & Aromadendren Epoksit $-(\mathrm{I})^{\mathrm{n}}$ \\
\hline 32 & 46.34 & 0.32 & Fenol. 2.6-dimethoksi- ${ }^{\mathrm{n}}$ \\
\hline 33 & 47.27 & 0.11 & Allil glisidil eter ${ }^{\mathrm{n}}$ \\
\hline 34 & 47.81 & 0.08 & ar-Abietatrien $^{n}$ \\
\hline 35 & 50.36 & 0.46 & Metil jjasmonat $^{\mathrm{n}}$ \\
\hline 36 & 51.37 & 0.24 & Talsutin $^{\text {n }}$ \\
\hline 37 & 52.75 & 0.10 & Etilamin. $\mathrm{N}$-etil-N-nitroso- ${ }^{n}$ \\
\hline 38 & 53.16 & 0.20 & 3.4-Dimethoksi-5-iodo-2.2'-bipyridine ${ }^{n}$ \\
\hline 39 & 54.1 & 0.39 & Temazepam $^{n}$ \\
\hline 40 & 54.23 & 0.45 & Fenol. (1.1-dimetilethil)-4-methoksi- ${ }^{\mathrm{n}}$ \\
\hline 41 & 55.36 & 0.64 & Podocarpa-1.8.11.13-tetraen-3-one. 14-isopropil-1.13-dimethoksi \\
\hline 42 & 56.09 & 0.39 & Pregn-4-ene-3.20-dione. 6.16-dimetil- ${ }^{\mathrm{n}}$ \\
\hline
\end{tabular}

Bileşenlerin bulunduğu gruplar; a: Monoterpen hidrokarbon, b: Oksijenli monoterpen, c: Monoterpen, d: Monosiklik monoterpen, e: Siskiterpen, f: Hidrokarbon Siskiterpen, g: Oksijenli Siskiterpen, j: Oksijenli Fenilpropanoid, k: Diterpen, m: Hidrokarbon, n: Diğer.

\section{Tartışma ve Sonuç}

Tıbbi bitkiler ve bitkisel ürünler (ekstrakt, uçucu yağ vs.) eski çağlardan beri insan ve hayvan hastalıklarının korunması ve tedavisinde kullanılmaktadır (Yipel ve Yipel, 2014). Tıbbi bitkiler 400 veya daha fazla kimyasal bileşenleri içerebilir. Günümüzde hayvan hastalıklarında tıbbi bitki ve ürünlerinin uzman olma-
Adıyaman'ın Kahta ilçesinde yapılan bir çalışmada $T$. spicata var. spicata L. bitkisi üç farklı dönemde (çiçeklenmeden önce, çiçeklenme dönemi ve çiçeklenmeden sonra) toplanmış ve hidrodistilasyon yöntemi ile uçucu yağları elde edilmiştir. Bu çalışmanın GC -MS analizi sonucunda 45'ten fazla bileşen belirlenmiştir. Karvakrol bileşeninin en yüksek oranı (\% 64.53) çiçeklenme sonrası, en düşük oranı (\%53.55) 
Tablo 4. Laurus nobilis L. bitkisi kimyasal bileşenleri

\begin{tabular}{|c|c|c|c|}
\hline Sıra & RT & Yüzde (\%) & Bileşen \\
\hline 1 & 6.56 & 2.40 & a-Pinen ${ }^{a}$ \\
\hline 2 & 8.39 & 1.12 & $\beta$-Pinen ${ }^{\mathrm{a}}$ \\
\hline 3 & 8.69 & 6.04 & Sabinen $^{a}$ \\
\hline 4 & 10.02 & 1.05 & Limonen $^{\mathrm{a}}$ \\
\hline 5 & 10.95 & 0.94 & $\beta$-Felandren ${ }^{a}$ \\
\hline 6 & 12.63 & 2.28 & $p$-Simen ${ }^{a}$ \\
\hline 7 & 19.61 & 0.60 & cis-Sabinen hidrat $^{a}$ \\
\hline 8 & 12.05 & 33.70 & Ökaliptol $(1,8 \text {-sineol })^{\mathrm{b}}$ \\
\hline 9 & 20.59 & 1.60 & Linalool $^{\mathrm{b}}$ \\
\hline 10 & 22.86 & 0.52 & trans Sabinen hidrat ${ }^{b}$ \\
\hline 11 & 24.15 & 2.41 & Terpinen-4-ol ${ }^{\mathrm{b}}$ \\
\hline 12 & 25.31 & 0.40 & Bornyl asetat ${ }^{b}$ \\
\hline 13 & 26.59 & 0.52 & $a-$ Terpineol $^{b}$ \\
\hline 14 & 27.49 & 22.28 & $a-$ Terpinil asetat $^{b}$ \\
\hline 15 & 27.72 & 0.29 & Linalil asetat ${ }^{\mathrm{b}}$ \\
\hline 16 & 29.50 & 0.35 & Mirtenol $^{b}$ \\
\hline 17 & 45.64 & 0.51 & Verbenol $^{\mathrm{C}}$ \\
\hline 18 & 27.14 & 0.31 & Alloaromadendren $^{d}$ \\
\hline 19 & 30.11 & 0.44 & Limonen oksit ${ }^{\mathrm{e}}$ \\
\hline 20 & 38.73 & 1.56 & Karyofilen Oksit ${ }^{\mathrm{e}}$ \\
\hline 21 & 40.39 & 0.88 & Spathulenol ${ }^{e}$ \\
\hline 22 & 43.31 & 0.69 & Metil izoöjenol $^{f}$ \\
\hline 23 & 22.64 & 0.29 & Elemen $^{9}$ \\
\hline 24 & 26.14 & 0.30 & Pinocarvone $^{g}$ \\
\hline 25 & 26.92 & 2.80 & L- $\alpha$-Terpineol ${ }^{\mathrm{g}}$ \\
\hline 26 & 28.64 & 0.44 & Myrtenal $^{9}$ \\
\hline 27 & 35.41 & 0.49 & cis-3-Heksenil iso-butirat ${ }^{g}$ \\
\hline 28 & 37.85 & 3.77 & Metil ögenol $^{9}$ \\
\hline 29 & 39.74 & 0.90 & Piperitenon oksit ${ }^{9}$ \\
\hline 30 & 39.92 & 0.47 & 8-Hidroksi linalool ${ }^{9}$ \\
\hline 31 & 40.50 & 0.37 & d-Glukozamin ${ }^{g}$ \\
\hline 32 & 40.66 & 1.49 & 3-Allil-6-metoksifenol ${ }^{g}$ \\
\hline 33 & 41.13 & 1.18 & cis-Verbenol $^{9}$ \\
\hline 34 & 41.87 & 0.31 & 1-Naphthalenol ${ }^{9}$ \\
\hline 35 & 43.01 & 0.32 & Guaiol $^{g}$ \\
\hline 36 & 43.63 & 1.37 & Eudesmo $^{g}$ \\
\hline 37 & 46.20 & 0.45 & Cinnamic asit. o-hidroksi- ${ }^{9}$ \\
\hline 38 & 46.40 & 0.32 & trans-Izoöjenol $^{9}$ \\
\hline 39 & 46.52 & 0.31 & 2-Metil-4-(2.6.6-trimetilsikloheks-2-enil)but-3-en-2-ol ${ }^{9}$ \\
\hline 40 & 48.30 & 0.95 & trans-p-Mentha-1(7).8-dien-2-ol ${ }^{9}$ \\
\hline 41 & 49.03 & 0.39 & cis-Asarone $^{g}$ \\
\hline 43 & 49.46 & 0.31 & 5-(1-Bromo-1-metiletil)-2-metilsikloheks-2-enon ${ }^{g}$ \\
\hline 44 & 49.79 & 0.38 & Nerolidol-epoksi asetat ${ }^{9}$ \\
\hline
\end{tabular}

Bileşenlerin bulunduğu gruplar; a: Monoterpen hidrokarbon, b: Oksijenli monoterpen, c: Monoterpen, d: Hidrokarbon Siskiterpen, e: Oksijenli Seskiterpen, f: Oksijenli Fenilpropanoid, g: Diğer.

ise çiçeklenme döneminden önce saptanmıştır. Bununla birlikte, y-terpinen oranı (\%19.45'ten \%14.29'a) bitkinin olgunlaşmasıyla azalmıştır (Inan ve ark., 2011). Saidi ve ark. (2012) yaptıkları çalışmada $T$. spicata var. spicata L. bitkisinden 46 farklı bileşen elde etmiştir ve ana bileşenler olarak karvakrol (\% $60.36)$, y-terpinen (\%15.09), $\beta$-mirsen (\%2.5), transkaryofilen (\%1.78), $\alpha$-tujen (\%1.54) ve timol (\%1.19) tanımlanmıştır. Bir diğer çalışmada karvakrol (\% $78.53)$, y-terpinen $(\% 10.42)$ ve $p$-simen $(\% 5,49)$ ana bileşenler olarak tespit edilmiş olup bu maddelerin yanında toplam 40 bileşen daha belirlemişlerdir (Bayan ve ark., 2017). Bu çalışma sonucunda ana bileşen olarak karvakrol ve $\mathrm{y}$-terpinen belirlenmiş olup bu bileşenlerin diğer çalışmalarda da yüksek oranda olduğu görülmüştür. Özellikle karvakrol maddesi $T$. spicata var. spicata L. bitkisinden elde edilen ekstrakt ve uçucu yağların önemli bir bölümünü oluşturmaktadır. T. spicata var. spicata L. bitkisinden yüksek miktarda elde edilen karvakrol genellikle tatlandırıcı olarak insan gıdalarında düşük oranda bulunmaktadır (Ündeğer ve ark., 2009). Karvakrol, gıda bozulmalarının ve gıda kaynaklı patojenik bakterilerin büyümesini kontrol etmede etkilidir (Suntres ve ark., 2015). Bakteri, mantar ve maya üzerindeki antimikrobiyal etkileri nedeniyle de yaygın olarak kullanılır. Ayrıca böcek öldürücü ve antioksidan özellikleri de vardır (Llana-Ruiz-Cabello ve ark., 2015). Karvakrol'ün farelerde intravenöz veya intraperitonal yolla uygulanması sonucunda ortalama ölümcül dozun 
$\left(L_{50}\right)$ sırasıyla 80.00 ve $73.30 \mathrm{mg} / \mathrm{kg}$ olduğu (Hagan ve ark., 1967; Suntres ve ark., 2015), ratlarda oral yolla uygulandığında ise ortalama ölümcül dozun $\left(L_{50}\right) \quad 810 \mathrm{mg} / \mathrm{kg}$ olduğu bildirilmiştir (Andersen, 2006; Suntres ve ark., 2015). İnsan lenfositleri üzerinde yapılan bir çalışmada ise karvakrol'ün $0.1,0.2$, 0.5 , 1 ve 2 mM konsantrasyonları DNA iplik kopmasına neden olmuştur (Aydın ve ark., 2005; Llana-RuizCabello ve ark., 2015).

T. spicata var. spicata L.'den elden edilen karvakrol ve timolün DNA ile etkileşimleri, tek iplikçik kopması, çift iplikçik kopmaları, baz hasarı ve diğerleri gibi çeşitli moleküler hasarlara neden olur. Yapılan bir çalışmanın sonucunda, karvakrol (70 mg/kg dozunda) ve timolün $(40,60,80$ ve $100 \mathrm{mg} / \mathrm{kg}$ dozlarında) sıçan kemik iliği hücrelerinde yapısal, sayısal ve toplam kromozom anormalliklerini indüklediği karvakrol ve timolün, mitotik indeksi azaltarak sitotoksik bir etkiye sahip olduğu belirlenmiştir (Azirak ve Rencuzogullari, 2008).

Bu sonuçlardan, karvakrol ve timolün büyük olasılıkla genotoksik bir risk taşıdığı sonucuna varılabilir. Bu nedenle, yiyecek, içecek, farmakoloji, parfümeri, kozmetik ve ilaç endüstrisinde antihelmintik, antiseptik, antifungal, antibakteriyel ve antiviral maddeler olarak kullanırken dikkatli olmak gerekir (Azirak ve Rencuzogullari, 2008).

$T$. spicata var. spicata L. bitkisinden y-terpinen bileşeni ikinci olarak yüksek oranda bulunmuştur. Karvakrol bileşeninde olduğu gibi bu madde de antimikrobiyal aktiviteye sahiptir. Bu sebeple patojenik mikroorganizmaların büyümesini geciktirmek veya inhibe etmek için kullanılabilirler. Gamma-terpinen toksikolojik olarak incelendiğinde, tek başına $0.2 \mathrm{mM}$ 'den başlayan konsantrasyonlarda insan lenfositlerinde DNA hasarına neden olduğu görülmüştür (Aydın ve ark., 2005).

Konya'da yapılan bir çalışmada $R$. officinalis L. bitkisinin hidrodistilasyonu ve GC-MS analizi sonucunda 20 biyoaktif bileşen tanımlanmıştır. Ana bileşenler $p$ simen (\%44.02), linalool (\%20.5), terpinen (\%16.62), timol (\%1.81), $\beta$-pinen (\%3.61), a-pinen (\%2.83) ve 1,8-sineol (ökaliptol) (\%2.64) olarak belirlenmiştir (Özcan ve Chalchat, 2008). Sardunya ve Korsika bölgelerinden toplanan $R$. officinalis $\mathrm{L}$. bitkisinin ana bileşenleri sırasıyla, a-pinen (\%13.7-24.6), bornil asetat (\%11.3-17.0), verbenon (\%4.4-24.9), kafur (\%2.9$14.1)$ ve 1,8 -sineol (ökaliptol) (\%3.4-11.3) olarak bulunmuştur (Pintore ve ark., 2002). R. officinalis L.bileşenlerinden ökaliptol (1,8-sineol) (\%8.7, \%49.8 ve $\% 40.0)$, a-pinen (\%34.0, \%18.7 ve $\% 23.5)$, kafur (\%11.7, \%12.6 ve \%13.2) ve borneol (\%16.9, \%7.1 ve \%4.6) Fas'ın Rabat, Errachidia ve Oujda şehirlerinde ana bileşenler olarak belirlenmiştir (Lahlou ve Berrada, 2003). Başka bir çalışmada R. officinalis L. bitkisinden kafur (\%18.9), verbenon (\%11.3), a-pinen
(\%9.6), $\beta$-mirsen (\%8.6), 1,8-sineol (ökaliptol) (\%8.0) ve $\beta$-karyofilen (\%5.1) bileşenleri tespit edilmiştir (Bernardes ve ark., 2010).

Mevcut çalışma sonucunda, $R$. officinalis L. bitkisinden elde edilen bileşenlerin oranları diğer çalışmalarda elde edilen bileşenlerin oranlarından farklı bulunmuştur. Bir çalışmada yazarlar bu farkın sebebini, farklı çevresel ve genetik faktörler, farklı kemotipler, bitkilerin beslenme durumu ve ayrıca yağ kompozisyonunu etkileyebilecek diğer faktörlerden kaynaklanabileceğini belirtmişlerdir (Özcan ve Chalchat, 2008). Hayvan sağlığı alanında birçok endikasyon için kullanılan $R$. officinalis $L$. bitkisi $P-450$ grubu bazı biyotransformasyon enzim (CYP1A, CYP2E, CYP3A) ve P-glikoprotein substratlarıyla diüretikler, insülin ve oral hipoglisemikler, siklofosfamid ve demirle istenmeyen etkileşim potansiyeline sahiptir. Ayrıca uterus kasılması nedeniyle aborta neden olabileceğinden gebe hayvanlarda kullanımı kontrendikedir (Wynn ve Fougere, 2006).

Laurus nobilis L. bitkisi için Kuzey Kıbrıs'da yapılan bir çalışmada 81 farklı bileşen tanımlanmıştır. Bu çalışmada bitkinin yapraklarından hidrodistilasyon yöntemi kullanarak yüksek oranda 1,8-sineol (ökaliptol) (\%58.59) belirlenmiştir. Elde edilen diğer ana bileşenler, sırasıyla $\alpha$-terpinil asetat $(\% 8.82)$ ve terpinen-4-ol (\%4.25) olarak belirlenmiştir (Yalçın ve ark., 2007). Antakya, Samandağı ve Yayladağı'ndan toplanan L. nobilis L. yapraklarının hidrodistilasyonu ve GC-MS analizi sonucunda 25 bileşen belirlenmiştir. Bu üç bölgeden toplanan bitkilerin kimyasal bileşenlerinde belirgin bir fark olmamakla birlikte, Antakya'dan toplanan bitkiden elde edilen sabinen ve $\alpha$ terpineol bileşenleri Yayladağı ve Samandağı'ndan toplanan bitkilerden elde edilen sabinen oranına kıyasla daha yüksek oranda bulunmuştur. Antakya, Yayladağı ve Samandağ bölgelerinden toplanan tüm yapraklarda 1,8-sineol oranı en yüksek bileşen olarak tespit edilmiştir. Diğer ana bileşen ise $\alpha$-terpinil asetat ve sabinen olarak belirlenmiştir (Sangun ve ark., 2007). Akdeniz, Ege, Marmara ve Karadeniz'den toplanan L. nobilis L. yapraklarının kimyasal bileşenlerinin araştırıldığı bir çalışmada GC-MS analizi sonucunda ana bileşen olarak 1,8-sineol (ökaliptol) (\% 31.87-67.56), a-terpinil asetat (\%4.09-22.22), $\alpha-$ terpineol (\%0.94-16.08), linalool (\%0.40-13.04), terpinen-4-ol (\%2.31-9.22) ve sabinen (\%0.56-9.08) bileşenleri tespit edilmiştir (Karık ve ark., 2015). Tunus'ta yürütülen, $L$. nobilis L. yapraklarından elde edilen uçucu yağların farklılıklarının (mevsimsel ve coğrafik) araştırıldığı diğer bir çalışmada, ana bileşenler 1,8-sineol (ökaliptol) (\%29.6), a-terpinenil asetat (\%13.6), metil ögenol (\%13.5), sabinen (\%5.6), linalool (\%4.7), a-pinen (\%4.1) ve terpinen-4-ol (\% 2.6) olarak bulunmuştur (Marzouki ve ark., 2009). Mevcut çalışmada L. nobilis L. bitkisinin GC-MS analizi sonucunda ana bileşen olarak belirlenen 1,8sineol (ökaliptol), diğer çalışmalarda da yüksek oran- 
larda olduğu görülmüştür. Diğer önemli bileşenler aterpinil asetat, terpinen-4-ol ve sabinen olarak belirlenmiştir.

$R$. officinalis $\mathrm{L}$. ve $L$. nobilis $\mathrm{L}$. bitkilerinde yüksek miktarda elde edilen 1,8-sineol (ökaliptol) genellikle gıda aroma maddesi olarak kullanılır. Bunun yanında antimikrobiyal, antienflamatuar ve antioksidan özellikleri de vardır (Xu ve ark., 2014). 1,8-sineol üst ve alt solunum yolu hastalıklarının (sinüzit, bronşit ve astım gibi) tedavisinde antienflamatuar amaçla kullanılmaktadır (Dörsam ve ark., 2015). Xu ve ark. (2014) farelerde 1,8-sineol maddesinin akut ve subakut toksisitesini araştırdıkları çalışmada maddenin $L D_{50}$ değerinin $3849 \mathrm{mg} / \mathrm{kg}$ olduğunu ve ölüm sebebinin solunum yetmezliğinden ileri geldiğini bulmuşlardır. 1,8-sineol bileşeninin $192.45 \mathrm{mg} / \mathrm{kg} / \mathrm{gün}$ dozunda alınması durumunda farelerde böbrek ve karaciğer hasarı şekillendiği tespit edilmiştir (Xu ve ark., 2014). Dörsam ve ark. (2015) tarafından yürütülen çalışmada 1,8-sineol maddesinin oksidatif stresi indüklediğini ve oksidatif DNA hasarına sebep olduğu ileri sürülmüştür.

1,8-sineolün kemirgenlerde akut, tekrarlanan dozlar ve üreme toksisitesi için klinik öncesi toksisitesi üzerine araştırma yapılmış, dişi farelerde oral $2000 \mathrm{mg} / \mathrm{kg}$ dozda 1,8-sineol uygulamasının başlangıçta zamanla yoğunlaşan sedasyon, tremor ve diyare belirtilerine yol açtığı, 24 saatten daha kısa bir sürede dispne ve nöbetler yanında tüm hayvanlarda ölüm meydana getirdiği bildirilmiştir. $1750 \mathrm{mg} / \mathrm{kg}$ dozda 24 saatten daha az bir sürede hayvanların yine tümünde ölüm meydana getirdiği bildirilmiştir. $1500 \mathrm{mg} / \mathrm{kg}$ dozunda hayvanlarda sedasyon ve tremor gözlenirken, ilk 24 saat içerisinde ya da takip edilen 14 gün boyunca hayvanlarda ölüm meydana gelmediği bildirilmiştir. $\mathrm{Bu}$ nedenle $1500 \mathrm{mg} / \mathrm{kg}<\mathrm{LD}_{50}<1750 \mathrm{mg} / \mathrm{kg}$ olduğu belirlenmiştir (Caldas ve ark., 2016).

Yapılan bir diğer akut toksisite çalışmasında, 1,8sineolün $L_{50}$ 'sinin yetişkin bir sıçandaki oral yol için $1280 \mathrm{mg} / \mathrm{kg}$ olduğu belirtilmiştir. $100 \mathrm{mg} / \mathrm{kg}$ '।lk dozlarda 1,8-sineol ile tedavi edilen hayvanlarda gözle görülür bir toksisite, solunum problemi, ataksi, konvülzyon veya mortalite belirtisi olmadığı bildirilmiştir (Jalilzadeh-Amin ve Maham, 2015). Diğer türlerdeki $\mathrm{LD}_{50}$ değerlerinin kobaylarda $2300 \mathrm{mg} / \mathrm{kg}$ (kas içi), köpeklerde $1500 \mathrm{mg} / \mathrm{kg}$ (deri altı) ve farede $50 \mathrm{mg} / \mathrm{kg}$ olduğu bildirilmiştir (McLean ve ark. 2007; JalilzadehAmin ve Maham, 2015).

$R$. officinalis L. bitkisinden elde edilen ve organik bir terpen bileşeni olan $\alpha$-pinenin, antioksidan, antienflamatuar ve antikanserojen özellikleri vardır (Biradar ve Veeresh, 2013). Yapılan bir araştırmada $\alpha$-pinen bileşeninin, ladin örümcek akarı Oligonychus ununguis (Jacobi) için toksik olduğu bulunmuştur (Cook, 1992). Ozbek ve ark. (2017) yaptıkları bir çalışmada a-pinen bileşeninin İsviçre albino farelerinde akut toksisitesini ve 18 saat perhizde bırakılan diyabetik hayvanlardaki hipoglisemik etkilerini değerlendirmiştir. Bu çalışma sonucunda intraperitoneal yolla verilen $L_{50}$ değeri toplam hayvan sayısı için $2.076 \mathrm{~mL} / \mathrm{kg}$ olduğu bulunmuştur. Ayrıca a-pinen bileşeninin açlık kan şekeri seviyesini önemli ölçüde azalttığı tespit edilmiştir (Özbek ve Yılmaz, 2017).

L. nobilis L. bitkisinde ayrıca yüksek oranda mutajenik ve genotoksik etkilere sahip $\alpha$-terpinil asetat tespit edilmiştir. Ratlarda yapılan bir çalışmada tekrarlanan doz toksisitesi için gözlenmeyen etki seviyesi 10000 ppm veya $400 \mathrm{mg} / \mathrm{kg} / \mathrm{gün}$ olarak düşünülmüştür. Sprague Dawley ırkı ratla $\alpha$-terpinil asetat $750 \mathrm{mg} / \mathrm{kg} /$ gün dozda oral yolla verilmesi sonucunda, erkeklerde epididimis kanalında dejenere spermatojenik hücre varlığı ile birlikte azalmış sayıda ya da tamamen spermatozoa yokluğu ve testislerde seminifer tubuler atrofi (orta ve şiddetli derecede) görülmüştür (Api ve ark., 2018).

Sonuç olarak hayvan sağlığı alanında bitki ve bitkisel ürünlerin kullanımının gün geçtikçe artmaktadır. Bu artış bitkilerin farmakolojik etkileri yanında kimyasal kompozisyonlarının ve ana bileşenlerinin olası toksik etkilerinin de bilinmesi zorunluluk haline gelmiştir. Dolayısıyla bitkilerden su distilasyonu, solvent ekstraksiyonu vb. yollarla elde edilen materyallerin içerdikleri biyoaktif kimyasal içerikleri ya da ana bileşen oranları ve olası toksik etkilerinin de ticari olarak satışa sunulan ürünlerde belirtilmesi, hayvan sağlığı uzmanları ya da hasta sahipleri tarafından kullanımları sonucu meydana gelebilecek olası toksik etkilerin en aza indirgenmesine katkı sağlayacaktır. Bitkisel materyalin elde edilme metodu ve kimyasal kompozisyonu doğrultusunda yapılacak deneysel in vitro ve in vivo çalışmalarla olası toksik etkilerin ve miktarlarının ortaya konulması da bu anlamda oldukça önemlidir. Bu çalışmalar ise kayıt altına alınarak gelecek nesillere yol göstermiş olacaktır.

\section{Kaynaklar}

Akkemik Ü. Türkiye'nin Doğal-Egzotik Ağaç ve Çalıları. Ankara: Orman Genel Müdürlüğü Yayınları 2018.

Al-Rubaye F, Kadhim MJ, Hameed IH. Phytochemical profiles of methanolic seeds extract of cuminum cyminum using GC-MS technique. Int J Curr 2017; 8 (2): 114-24.

Al-Sereiti MR, Abu-Amer KM, Sena P. Pharmacology of rosemary (Rosmarinus officinalis Linn.) and its therapeutic potentials. Indian J Exp Biol 1999; 37: 124-30.

Altınok Yipel F, Yipel M. Etnoveteriner hekimlik (EVH). TVHB Dergisi 2014; 14(1-2): 79-82.

Andersen A. Final report on the safety assessment of sodium p-chloro-m-cresol, p-chloro-m-cresol, chlorothymol, mixed cresols, m-cresol, o-cresol, $\mathrm{p}$ - 
cresol, isopropyl cresols, thymol, o-cymen-5-ol, and carvacrol. Int J Toxicol 2006; 25(1): 29-127.

Api AM, Belsito D, Botelho D, Bruzec M, Burton Jr. GA, Buschmanne J, Daglif ML, Datea M, Dekantg W, Deodhara C, Francisa M, Fryerh AD, Jonesa L, Joshia K, La Cavaa S, Lapczynskia A, Liebleri DC, O'Briena D, Patela A, Penningj TM, Ritaccoa G, Rominea J, Sadekara N, Salvitoa D, Schultzk TW, SipesI IG, Sullivana G, Thakkara Y, Tokuram Y, Tsanga S. RIFM fragrance ingredient safety assessment, terpinyl acetate (Isomer Mixture), CAS registry number 8007-35-0. Food and Chem Toxicol 2018; 122: 362-71.

Aydın S, Başaran AA, Başaran N. Modulating effects of thyme and its major ingredients on oxidative DNA damage in human lymphocytes. J Agric Food Chem 2005; 53(4): 1299-305.

Azcan N, Kara M, Asilbekova DT, Ozek, T, Baser KHC. Lipids and essential oil of Origanum onites. Chem Nat Compd 2000; 36(2): 132-6.

Azirak S, Rencuzogullari $\mathrm{E}$. The in vivo genotoxic effects of carvacrol and thymol in rat bone marrow cells. Environ Toxicol 2008; 23(6): 728-35.

Bayan Y, Genc N, Kusek M, Gul F, Imecık Z. Determination of chemical compositions, antifungal, antibacterial and antioxidant activity of Thymbra spicata L. from Turkey. FEB Fresenius Environ Bull 2017; 26: 7595-9.

Benli M, Yiğit N. Ülkemizde yaygın kullanımı olan kekik (Thymus vulgaris) bitkisinin antimikrobiyal aktivitesi. Orlab On-Line Mikrobiyoloji Dergisi 2005; 3(8): 1-8.

Bernardes WA, Lucarini R, Tozatti MG, Bocalon FlauzinoLG, SouzaMGM, TurattilCC, Andrade e Silva ML, MartinsCHG, A. da Silva Filho A,Cunha WR. Antibacterial activity of the essential oil from rosmarinus officinalis and its major components against oral pathogens. Z Naturforschung C 2010; 65(9-10): 588-93.

Biradar S, Veeresh B. Preclinical evolutionary study of alpha-pinene in I-arginine iınduced acute pancreatitis in rat. Indian J Pharm Educ Res 2013; 41: 738.

Caldas GFR, Limeira MMF, Araújo AV, Albuquerque GS, Silva-Neto JC, da Silva TG, da Costa-Silva JH, de Menezes IRA, da Costa JGM, Wanderley AGI. Repeated-doses and reproductive toxicity studies of the monoterpene 1,8-cineole (eucalyptol) in Wistar rats. Food Chem. Toxicol 2016; 97; 297-306.

Cook SP. Influence of monoterpene vapors on spruce spider mite, Oligonychus ununguis, adult females. J Chem Ecol 1992; 18(9): 1497-504.

Dörsam B, Wu CF, Efferth T, Kaina B, Fahrer J. The eucalyptus oil ingredient 1,8-cineol induces oxidative DNA damage. Arch Toxicol 2015; 89(5): 797805.

George P. Concerns regarding the safety and toxicity of medicinal plants-An overview. J Appl Pharm Sci 2011; 1(6): 40-4.

Güzel Y, Güzelşemme M, Miski M. Ethnobotany of medicinal plants used in Antakya: A multicultural district in Hatay province of Turkey. J Ethnopharmacol 2015; 174: 118-52.

Hagan EC, Hansen WH, Fitzhugh OG, Jenner PM, Jones WI, Taylor JM, Long EL, Nelson AA, Brouwer JB. Food flavourings and compounds of related structure. II. subacute and chronic toxicity. Fd Cosmet Toxicol 1967; 5: 141-57.

Inan M, Kirpik M, Kaya DA, Kırıcı S. Effect of harvest time on essential oil composition of Thymbra spicata L. growing in flora of Adıyaman. Adv in Environ Biol 2011; 5(2): 356-8.

Jalilzadeh-Amin G, Maham M. The application of 1,8cineole, a terpenoid oxide present in medicinal plants, inhibits castor oil-induced diarrhea in rats. Pharm Biol 2015; 53(4): 594-9.

Karaoğlan EES, Özgen U. Bazı origanum türleri üzerinde farmakognozik çalışmalar, Doktora tezi, Atatürk Üniv Sağ Bil Ens, Erzurum 2011; s. 4-161.

Karık Ü, Çiçek F, Tutar M, Ayas F. Türkiye defne (Laurus nobilis L.) populasyonlarının uçucu yağ bileşenleri. Anadolu ETAE Dergisi 2015; 25(1): 116.

Kendir G, Güvenç A. Etnobotanik ve Türkiye'de yapılmış etnobotanik çalışmalara genel bir bakış. J Fac Pharm Hacettepe Univ 2010; 30(1): 49-80.

Lahlou M, Berrada R. Composition and niticidal activity of essential oils of three chemotypes of Rosmarinus officinalis $\mathrm{L}$. acclimatized in Morocco. Flavour Fragr J 2003; 18(2): 124-7.

Lee SJ, Umano K, Shibamoto T, Lee KG. Identification of volatile components in basil (Ocimum basilicum L.) and thyme leaves (Thymus vulgaris L.) and their antioxidant properties. Food Chem 2005; 91: 131-7.

Llana-Ruiz-Cabello M, Pichardo S, Maisanaba S, Puerto M, Prieto AI, Gutiérrez-Praena D, Jos A, Cameán AM. In vitro toxicological evaluation of essential oils and their main compounds used in active food packaging: A review. Food Chem Toxicol 2015; 81: 9-27. 
Marzouki HA, Elaissi A, Khaldi S, Bouzid S, Falconieri D, Marongiu B, Piras A, Porcedda S. Seasonal and geographical variation of Laurus nobilis $\mathrm{L}$. essential oil from Tunisia. Open Nat Prod J 2009; 1 : 86-91

McLean S, Boyle RR, Brandon S, Davies NW, Sorensen JS. Pharmacokinetics of 1,8-cineole, a dietary toxin, in the brushtail possum (Trichosurus vulpecula): significance for feeding. Xenobh 2007; 37: $903-22$

Mert A, Türkmen $M$, Bahadirli NP, Kaya DA, Ayanoğlu F, Özturk Ş. Effects of different drying methods on components of Thymbra spicata L. essential from flora of Hatay (Turkey). Sixth International Conference on Advanced Materials and Systems (ICAMS). October, 20-22, 2016; BucharestRomania.

Özbek H, Yılmaz BS. Anti-inflammatory and hypoglycemic activities of alpha-pinene. Acta Pharm Sci 2017; 55(4): 7-14.

Özcan MM, Chalchat JC. Chemical composition and antifungal activity of rosemary (Rosmarinus officinalis L.) oil from Turkey. Int J Food Sci Nutr 2008; 59(7-8): 691-8.

Peixoto ITA, Furletti VF, Anıbal PC, Duarte MCT, Höfling JF. Potential pharmacological and toxicological basis of the essential oil from Mentha spp. Rev Cienc Farm Basica Apl 2010; 30(3): 235-9.

Pintore G, Usai M, Bradesi P, Juliano C, Boatto G, Tomi F, Chessa M, Cerri R, Casanova J. Chemical composition and antimicrobial activity of Rosmarinus officinalis $\mathrm{L}$. oils from Sardinia and Corsica. Flavour Fragr J 2002; 17(1): 15-9.

Saidi M, Ghafourian S, Zarin-Abaadi M, Mohavedi K, Sadeghifard N. In vitro antimicrobial and antioxidant activity of black thyme (Thymbra spicata L.) essential oils. Roum Arch Microbiol Immunol 2012; 71: 619.

Sangun MK, Aydin E, Timur M, Karadeniz H, Calıskan M, Ozkan A. Comparison of chemical composition of the essential oil of Laurus nobilis L. Leaves and fruits from different regions of Hatay, Turkey. J Environ Biol 2007; 28(4): 731-3.

Suntres ZE, Coccimiglio J, Alipour M. The bioactivity and toxicological actions of carvacrol. Crit Rev Food Sci Nutr 2015; 55(3): 304-18.

Tohidi B. Rahimmalek M, Arzani A. Essential oil composition, total phenolic, flavonoid contents, and antioxidant activity of thymus species collected from different regions of Iran. Food Chemistry 2017; 220: 153-61.
Ündeğer Ü, Başaran A, Degen GH, Başaran N. Antioxidant activities of major thyme ingredients and lack of (oxidative) DNA damage in V79 Chinese hamster lung fibroblast cells at low levels of carvacrol and thymol. Food and Chem Toxicol 2009; 47 (8): 2037-43

Wynn SG, Fougere B. Veterinary Herbal Medicine. Sydney: Elsevier Health Sciences 2006.

Xu J, Hu ZQ, Wang C, Yin ZQ, Wei Q, Zhou LJ, Du YH, Jia RY, Li M, Fan QJ, Liang XX, He CL, Yin LZ. Acute and subacute toxicity study of 1,8 -cineole in mice. Int J Clin Exp Patho 2014; 7(4): 1495-501.

Yalçın H, Anık M, Şanda MA, Çakır A. Gas chromatography/ mass spectrometry analysis of Laurus nobilis essential oil composition of northern cyprus. J Med Food 2007; 10(4): 715-9.

Yipel FA, Yipel M. Etnoveteriner hekimlik (EVH). TVHB 2014; (1-2): 79-82.

Yipel M, Tekeli IO, Sevin S, Yarsan E. Veterinary phytotherapy in cancer therapy: popular medicinal plants and classification by mechanisms or target organ/system. International Veterinary Students Congress. February, 16, 2018; Ankara-Turkey.

Yipel M, Yipel FA, Tekeli IO, Güzel Y. Ethnoveterinary uses of medicinal plants in Mediterranean district, Turkey. Rev Chim 2017; 68(2): 411-6. 